\title{
RANCANG ULANG PROSES PENJERNIHAN AIR DALAM MENINGKATKAN KUALITAS PRODUKSI PERUSAHAAN DAERAH AIR MINUM (Studi Kasus Pada PT. Traya Tirta Cisadane - Serpong)
}

\author{
Antoni Maulana \\ Dosen Fakultas Teknik Prodi Teknik Industri Universitas Pamulang \\ dosen01311@unpam.ac.id
}

\begin{abstract}
ABSTRAK
Salah satu faktor penting penggunaan air dalam kehidupan sehari-hari adalah untuk kebutuhan air minum. Untuk mencapai kualitas air tersebut digunakan metode Seven Tools dalam mencari akar permasalahan terhadap produk yang kurangsempurna, sehingga dapat mengetahui penyebab-penyebab terjadinya cacat untuk menunjang cara tersebut penulis hanya membatasi dari tiga parameter saja yaitu pengelolaan sumber daya manusia, pengoperasian dan pemeliharaan Water Treatment Plant (WTP) bertujuan untuk menjaga agar produksi air minum memenuhi Kualitas, Kuantitas dan Kontinuitas serta sesuai Keputusan Menteri Kesehatan no. 32 tahun 2017 tentang syarat-syarat dan pengawasan kualitas air minum dan parameter kualitas air bersih.
\end{abstract}

Kata Kunci: Perancangan, Kualitas, Seven Tools.

\section{PENDAHULUAN}

Air merupakan unsur yang tidak dapat dipisahkan dari kehidupan manusia,.Oleh karena itu pengembangan dan pengolahan sumber daya air merupakan dasar peradaban manusia.Dari peranan air di atas, maka dapat di ambil kesimpulan bahwa salah satu faktor penting penggunaan air dalam kehidupan sehari-hari adalah untuk kebutuhan air minum.

Menurut Direktorat Jendral Cipta Karya, Pekerjaan Umum tahun 2017 standart kriteria kebutuhan air dibagi menjadi lima wilayah, antara lain Kecamatan, Kabupaten, Kota Sedang, Kota Besar dan Metropolitan dimana rata - rata kebutuhan air di kota Metropolitan antara 150 sampai 200 liter orang perhari dan rata - rata sebuah Kecamatan antara 60 sampai 100 liter orang perhari hal tersebut dapat dihitung dari kegiatan rumah tangga sehari - hari seperti mandi, cuci dan kakus dimana semakin banyak jumlah penduduknya semakin besar jumlah kebetuhan airnya

Tabel 1 Kategori air

\begin{tabular}{|c|c|c|c|}
\hline No & Katagori Kota & Jumlah Penduduk (Jiwa) & $\begin{array}{c}\text { Pengguna Air } \\
\text { (Liter/Orang/Hari) }\end{array}$ \\
\hline 1 & Metropolitan & $>1.000 .000$ & $150 \mathrm{~s} / \mathrm{d} 200$ \\
\hline 2 & Kota Besar & $500.000 \mathrm{~s} / \mathrm{d} 1.000 .000$ & $120 \mathrm{~s} / \mathrm{d} 150$ \\
\hline 3 & Kota Sedang & $100.000 \mathrm{~s} / \mathrm{d} 500.000$ & $100 \mathrm{~s} / \mathrm{d} 120$ \\
\hline 4 & Kabupaten & $20.000 \mathrm{~s} / \mathrm{d} 100.000$ & $90 \mathrm{~s} / \mathrm{d} 110$ \\
\hline 5 & Kecamatan & $3.000 \mathrm{~s} / \mathrm{d} 20.000$ & $60 \mathrm{~s} / \mathrm{d} 100$ \\
\hline
\end{tabular}

Dari tabel di atas Kota Tangerang Selatan termasuk dalam kategori Metropolitan, karena memiliki jumlah penduduk 1.644.899 jiwa berdasarkan data Badan Pusat Statistik tahun 2017, dimana kebutuhan airnya antara 150 sampai 200 liter orang perhari

Tabel 2 Penggunaan Air

\begin{tabular}{|lccccc|}
\multicolumn{1}{r}{ Kecamatan } & $\mathbf{2 0 1 3}$ & $\mathbf{2 0 1 4}$ & $\mathbf{2 0 1 5}$ & $\mathbf{2 0 1 6}$ & $\mathbf{2 0 1 7}$ \\
\hline Setu & $\mathbf{7 5 0 0 2}$ & $\mathbf{7 7 8 8 1}$ & 80811 & 83777 & 86783 \\
Serpong & 157252 & 163915 & 170731 & 177677 & 184761 \\
\hline Pamulang & 314931 & 323957 & 332984 & 341967 & 350923 \\
\hline Ciputat & 212824 & 219384 & 225974 & 232559 & 239152 \\
\hline Ciputat Timur & 193484 & 197960 & 202386 & 206729 & 211003 \\
\hline Pondok Aren & 341416 & 353904 & 366568 & 379354 & 392284 \\
\hline Serpong Utara & 148494 & 155998 & 163755 & 171749 & 179993 \\
\hline Kota Tangerang & 1443403 & 1492999 & 1543209 & 1593812 & 1644899 \\
Selatan & & & & & \\
& & & & &
\end{tabular}

Untuk memenuhi kebutuhan air tersebut warga Kota Tangerang Selatan masih banyak mengandalkan air tanah atau sumur dimana menurut Direktorat Jendral Cipta Karya, Pekerjaan Umum besaran air non domestik sendiri adalah $20 \%$ dari jumlah air domestik dan cadangan air sebesar 10\% tergantung luas wilayahnya. Air non domestik sendiri diartikan sebagai kebutuhan air di luar rumah tangga atau mandi, cuci dan kakus.

\section{DASAR TEORI}

\section{A.Definisi Kualitas}

Kualitas adalah keseluruhan karakteri stikproduk dan jasa yang melputi market ingengineering, manufaceturedan maintenanc 
edimana produk dan jasa tersebut dala mpemakaiannya akan sesuai dengan kebutuhan dan harapan pelanggan. (Dorothea, 2004:3), sedangkan menurut ISO 8402 (Loh, 2001:35), Kualitas adalahtotalitas fasilitas dan karakteristik dari produk atau jasa yang memenuhikebutuhan, tersurat mau pun tersirat.

\section{B. Kualitas Pengolahan Air Minum di Indonesia}

Pengoperasian dan pemeliharaan Water Treatment Plant (WTP) bertujuan untuk menjaga agar produksi air minum memenuhi Kualitas, Kuantitas dan Kontinuitas serta sesuai Keputusan Menteri Kesehatan no. 32 Tahun 2017 tentang Standar Baku Mutu Kesehatan Lingkungan dan Persyaratan Kesehatan Air untuk Keperluan Higine Sanitasi. Langkahlangkah pengoperasian dan pemeliharaan (WTP) Water Treatment Plant meliputi :

a) Perencanaan dan pengawasan

b) Pengendalian mutu proses

c) Pemeriksaan mutu akhir

d) Penanganan gangguan alat atau proses

e) Pemeliharaan (WTP) Water Treatment Plant

\section{D.Diagram Pareto}

Diagram pareto bias juga disebut gambaran pemisah unsur penyebab yang paling dominan dari unsur penyebab lainya dari satu masalah.

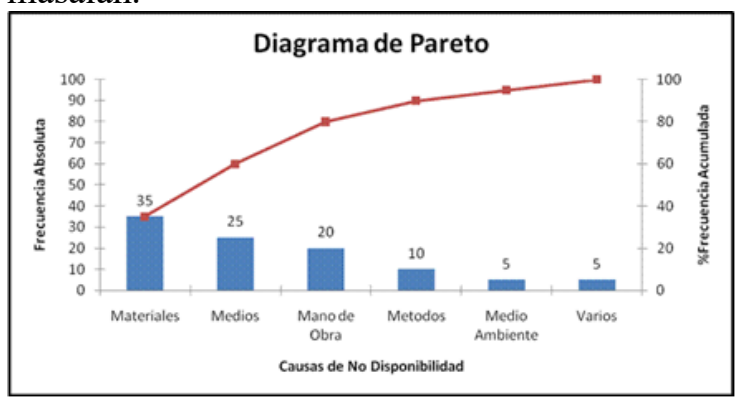

\section{E.Histogram}

Adapun karakteristik histogram adalah :

1. Histogram menjelaskan variasi proses, namun belum mengurutkan rangking dari variasi terbesar sampai dengan yang terk ecil.

2. Gambar bentuk distribusi (cacah) karak eristik mutu yang dihasilkan olehdata yang dikumpulkan melalui checksheet.

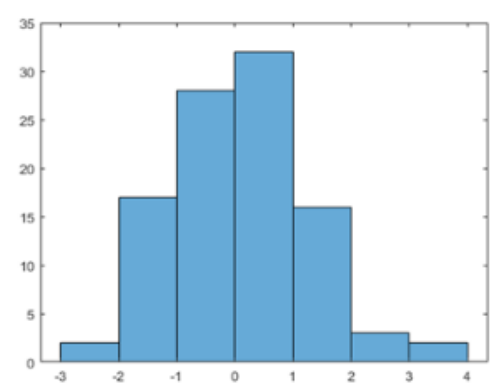

\section{F. Cek Sheet}

Lembar isian (check sheet) mer upakanalat bantu untuk memudahkan dan menyederhanakan pencatatan data. Bentuk dan isinya disesuaikandengan kebutuhan maupun kondisi kerja yang ada.

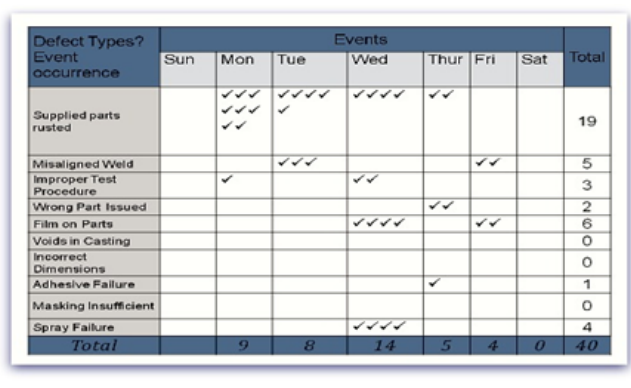

Gambar Cheek Sheet

\section{G. Fish Bone Diagram}

Istilah lain dari Fishbone Diagram adalah Diagram Ishikawa, dikembangkan oleh Kaoru Ishikawa seorang pakar kendali mutu. Sering kali disebut sebagai fishbone diagram dikarenakan bentuknya yang menyerupai tulang ikan.

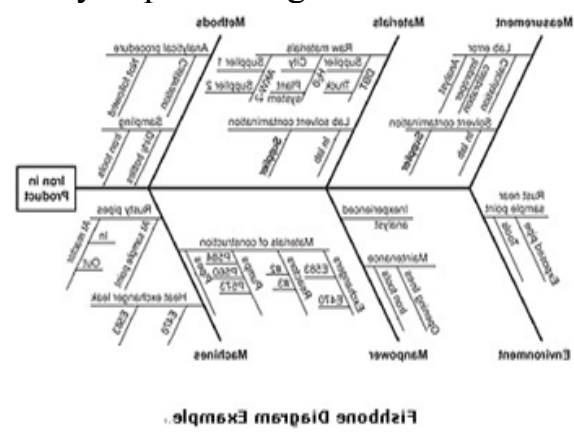

Gambar Diagram Fishbone

\section{G. Diagram Sccater}

Scatter diagram merupakan cara yang paling sederhana untuk menen tukanhubungn antara sebab dan akibat dari dua variabel atau untuk menent ukan korelasi antara penyebab yang diduga dengan akibat yang timbul dari suatu masalah. 


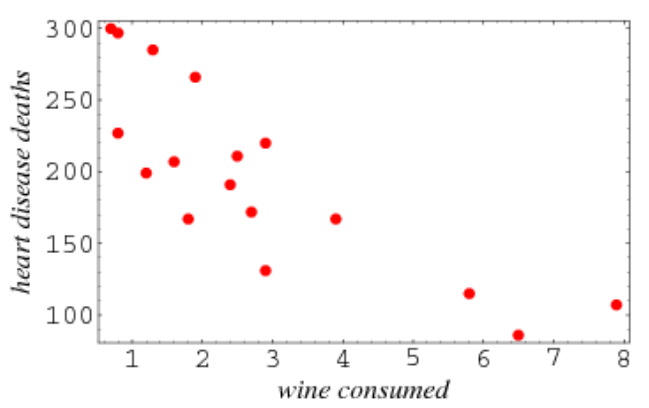

Gambar Diagram pencar

\section{H. Brain Storming}

Data Brain Storming bersifat kuantitatif. Karna disebut sebagai kumpulan data berupa pernyataan pernyataan yang diucapkan olehanggota forum atau rapat, dengan tujuan untuk menggali masukanmasukan yang diperoleh dari anggota tersebut.

\section{Grafik dan Peta Kendali (Control Chart)}

Control Chart adalah grafik yang digunakan untuk mengkaji perubahan proes dari waktu ke waktu. Merupakan salah satu alat atau tools dalam pengendalian proses secara statististik yang sering kita ke nal dengan SPC (Statistical Proces Control), ada juga yang menyebutnya dengan Seven Tools. Pembuatan control chart dalam SPC bertujuan untuk mengidentifikasi setiap kondisi didalam proses yang tidak terkendali secara statistik (out ofcontrol) karena pengendaliannya terhadap proses maka control chart terma suk ke dalam aktivitas on line quality con trol.

\section{Control Chart}

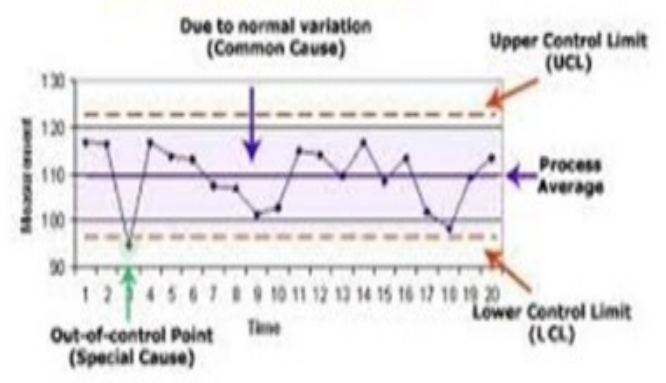

Gambar Diagram Control Chart

\section{J. Model Penelitian}

Berdasarkan landasan teori tersebut maka dapat dijadikan sebagai model penelitian sebagai berikut:

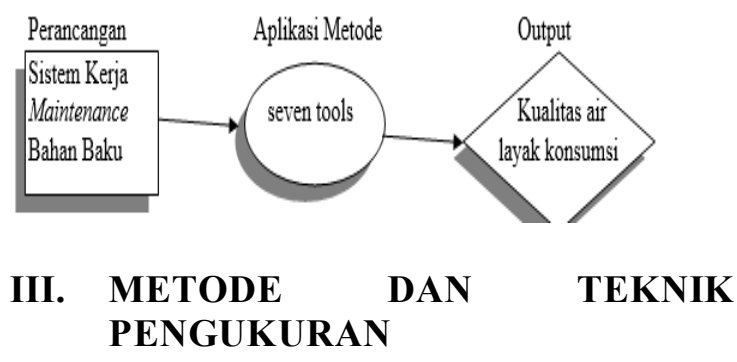

\section{A. Instrument Penelitian}

Menurut Suharsimi dalam buku Metodologi Penelitian (2012), instrumen adalah alat pengumpul data penelitian, sehingga harus dapat dipercaya, benar dan dapat sehingga harus dapat dipercaya, benar dan dapat dipertanggung jawabkan secara ilmiah (valid), oleh karena itu instrumen harus valid dan reliabel.

\section{B. Alat untuk Mengumpulkan Data}

Kuisioner yang dilakukan bertujuan untuk mengetahui karakteristik seluruh karayawan di Departmen Maintenance. Dari hasil tabulasi pivot kuesioner pendahuluan dapat terlihat dengan jelas perbedaan karakteristik karyawan yang ditinjau dari segi usia, lamanya pengalaman kerja, status pernikahan, tanggapan mereka terhadap penerapan shift kerja lama, dan tanggapan mereka apabila shift kerja yang selama ini berlaku di perusahaan diubah.

\section{C.Populasi dan Sampel}

Populasi adalah totalitas dari semua obyek atau individu yang akan diteliti yang memiliki karakteristik tertentu, jelas da nlengkap. Sedangkan sampel merupaka nbagian dari populasi yang diambil melalui cara-cara tertentu yang juga memiliki karakteristik tertentu,jelas, dan lengkap yang dianggap bisa mewakili populasi.

Populasi dari penelitian ini adalah seluruh seluruh operator yang berkerja shifting di PT. Traya Tirta Cisadane - Serpong, Tangerang Selatan sebanyak 70 orang, dengan kriteria sampel sebagai berikut :

1. Responden dalam keadaan sehat dan bisa di ajak berkomunikasi dua arah.

2. Terdaftar sebagai pegawai PT. Traya Tirta Cisadane - Serpong, Tangerang Selatan.

3. Bersedia menjadi responden 


\section{D.Flowchart Penelitian}

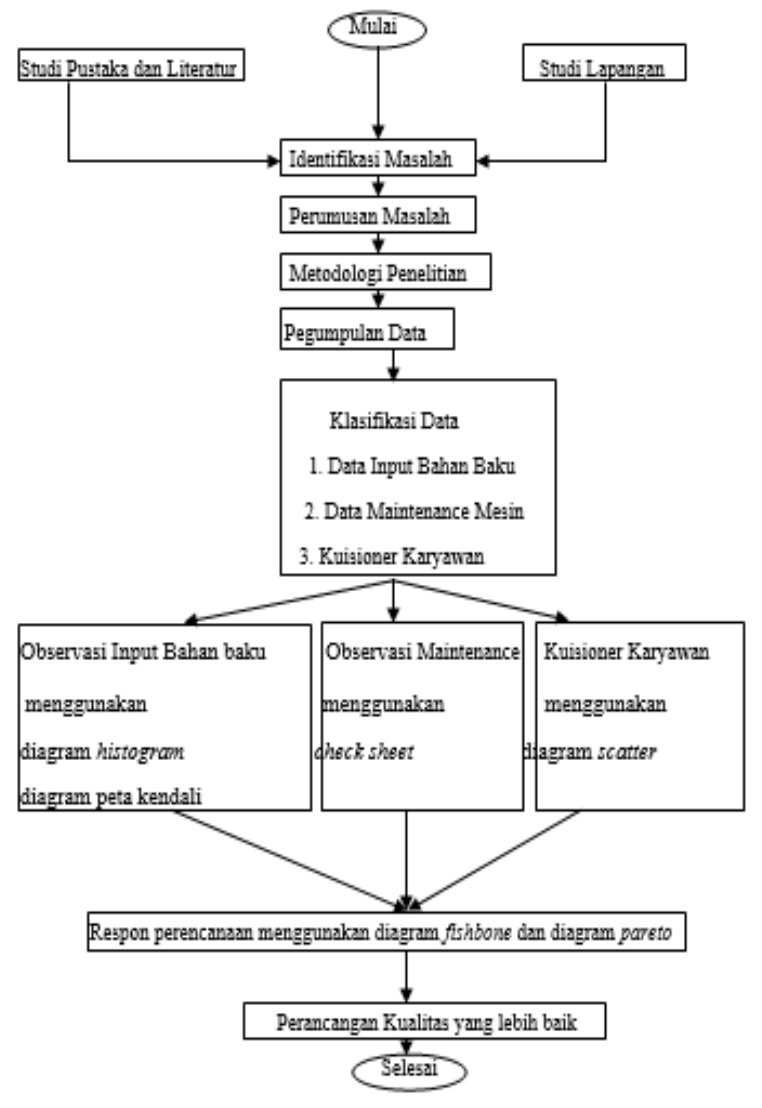

Gambar:Flowchart penelitian

\section{HASIL DAN PEMBAHASAN}

\section{A. Sejarah PT. Tirta Cisadane}

Dengan maksud memenuhi kebutuhan air bersih bagi masyarakat, dimana dari PDAM Tangerang masih jauh dari sasaran yang ingin dicapai,maka upaya yang dilak ukan adalah malaksanakan pembangunan melalui pengembangan0 kerjasama dengan pihak swasta, yaitu PT Tirta Cisadane. Pada tanggal 22April 1996 PDAM

Kabupaten Dati IITangerangmenandatangani perjanjian Kerjasama pengelolaan instalasi air minum Dengan PT Tirta Cisadane.

Pengolahannya didesain oleh sorang Degremont Perancis. Instalasi ini selesai di bangun pada tahun 1996 dantelah memasok airnya keJakarta pada tahunyang sama. Kerj asama dengan pihak swastaini menggunakan bentuk kontrak kelola yang berjangka wa ktu 15 tahun.

\section{B.Analisis Data}

Analisis data merupakan kesimpulan dari hasil penelitian dan pembahasan serta berupaya memberikan saran-saran yang mungkin dapat dijadikan bahan rekomendasi dan ataupun untuk dikembangkan kepenelitian lebih lanjut.

Berikut ini contoh gambar diagram Histogram Input Bahan Baku bulan Januari sampai dengan Maret 2017.

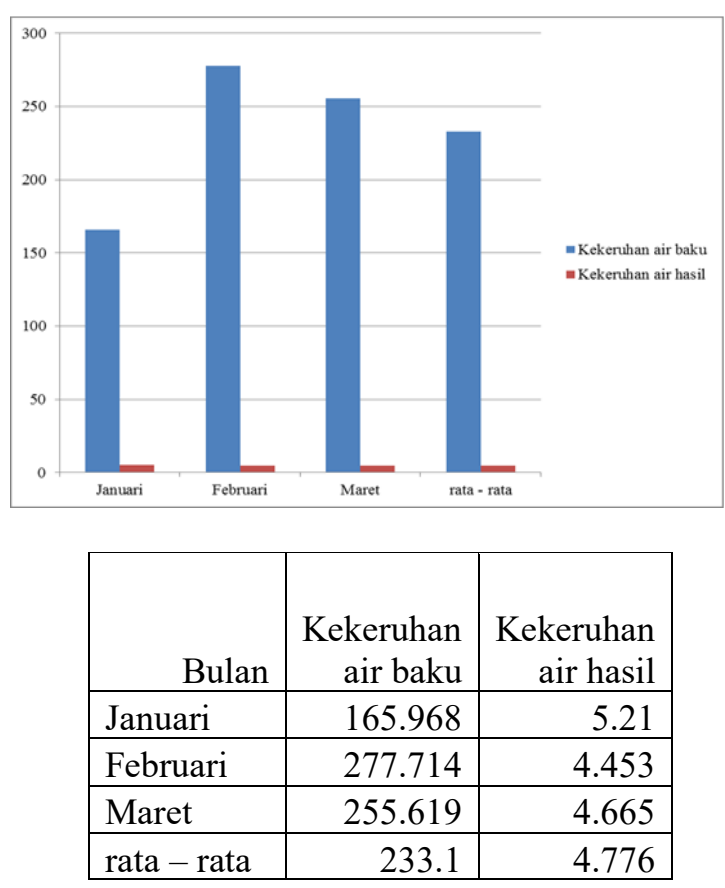

Setelah mengetahui tingkat kekeruhan, lalu dilanjutkan ke pengukuran derajat keasaman atau $\mathrm{PH}$ pada diagram berikut:

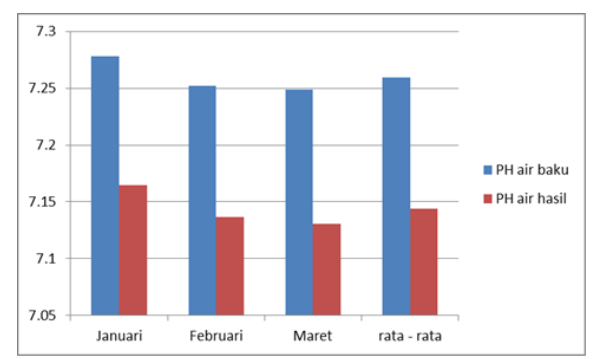

\begin{tabular}{|l|r|r|}
\hline \multicolumn{1}{|c|}{ Bulan } & PH air baku & PH air hasil \\
\hline Januari & 7.277742 & 7.164516 \\
\hline Februari & 7.252143 & 7.136786 \\
\hline Maret & 7.249032 & 7.130645 \\
\hline rata - rata & 7.259639 & 7.143982 \\
\hline
\end{tabular}

Berikut ini Control Chart derajat kesaman air bulan Januari sampai dengan Maret 2017 di PT. Tirta Cisadane. Pada grafik yang ditunjukan mengenai derajat keasaman sebelum dan sesudah dilakukan proses pengolahan air baku menjadi air layak 
konsumsi, diketahui masih dalam batas yang ditentukan oleh Keputusan Menteri Kesehat an no. 907/MENKES/SK/VII/2002 tentang s yaratsyarat dan pengawasan kualitas air minum dan parameter kualitas air bersih yang ditetapkan dalam PERMENKES 416/1990.

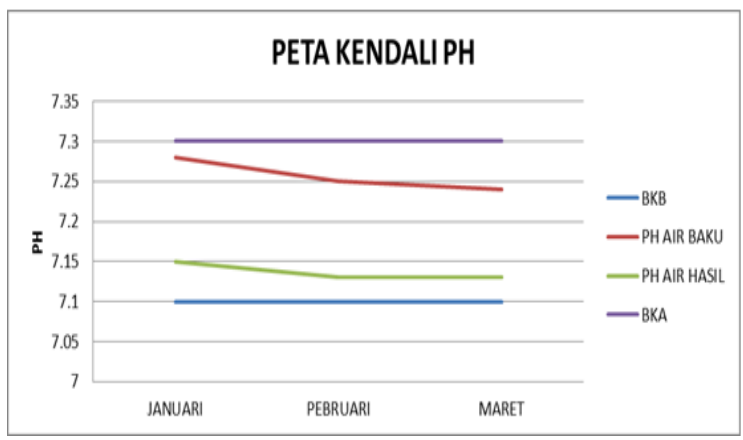

Maintenance sesuai ISO 9001 : 2000 dan ISO/IEC 17025:2005. Pengelolaan Sumber daya dapat dilakukan melalui preventive maintenance dan kalibrasi. Preventive maintenance dilakukan dengan tujuan untuk:

a. Memperpanjang waktu pakai dan mempertahankan kinerja mesin / alat.

b. Pemeriksaan peralatan untuk mengetahui lebih awal kelainan pada mesin / Alat. Preventive maintenance dilakukan secara berkala dengan perlakuan yang berbeda untuk setiap periode, contoh:

1) Preventive harian, pemeriksaan Temperatur bearing pompa

2) Preventive mingguan, Cleaning sensor $\mathrm{pH}$ air baku

3) Preventive bulanan, cleaning strainer pompa, Pemeriksaan Ampere pompa.

4) Preventive tahunan Overhoul pompa Kalibrasi dilakukan dengan tujuan untuk menentukan kebenaran konvensional dari penunjukkan alat ukur dan bahan ukur.

Kalibrasi dilakukan secara berkala untuk setiap alat ukur yang dikalibrasi, contoh:

a. Kalibrasi 6 bulanan, kalibrasi Flow Meter air bersih.

b. Kalibrasi tahunan, kalibrasi Flow Meter air baku dan level regulating tank.

Standar operasi peralatan digunakan sebagai parameter / acuan suatu alat / mesin dalam pengoperasiannya, sehingga dapat mengoptimalkan kinerja alat dalam standar yang aman. Standar tersebut dapat berupa:

a. Batasan Inspeksi dan Uji.

a. Sistem manajemen mutu ISO 9001:2000 dan sistem manajemen laboratorium ISO/IEC 17025:2005
Check Sheet Preventive maintenance dan Kalibrasi alat atau mesin dalam waktu mingguan, bulanan dan tahunan sesuai manual book, ISO 9001: 2000 dan sistem manajemen laboratorium ISO/IEC 17025:2005 terdapat pada kolom lampiran. Tabel tersebut sangat membantu terlaksananya keandalan perlatan dan memberikan keawetan dalam pengoperasian mesin-mesin produksi.

\section{Tabulasi Pivot Data Kuesioner}

Kuesioner yang dilakukan bertujuan untuk mengetahui karakteristik seluruh karayawan di Departmen Maintenance. Dari hasil tabulasi pivot kuesioner pendahuluan dapat terlihat dengan jelas perbedaan karakteristik karyawan yang ditinjau dari segi usia, lamanya pengalaman kerja, status pernikahan, tanggapan mereka terhadap penerapan shift kerja lama, dan tanggapan mereka apabila shift kerja yang selama ini berlaku di perusahaan diubah

Tabel Tabulasi Pivot Data Kuisioner

\begin{tabular}{|c|c|c|}
\hline Karakteristik & $\begin{array}{l}\text { Jumlah } \\
\text { (Orang) }\end{array}$ & $\begin{array}{c}\text { Prosentase } \\
\text { (\%) }\end{array}$ \\
\hline \multicolumn{3}{|l|}{ A. Usia } \\
\hline $30-35$ Tahun & 54 & $77 \%$ \\
\hline $36-40$ Tahun & 8 & $11 \%$ \\
\hline $41-45$ Tahun & 7 & $10 \%$ \\
\hline $45-50$ Tahun & 1 & $1 \%$ \\
\hline \multicolumn{3}{|l|}{ B. Pengalaman } \\
\hline $1-5$ Tahun & 6 & $9 \%$ \\
\hline $6-10$ Tahun & 27 & $39 \%$ \\
\hline $11-15$ Tahun & 35 & $50 \%$ \\
\hline $16-20$ Tahun & 2 & $3 \%$ \\
\hline \multicolumn{3}{|l|}{ C. Status Pernikahan } \\
\hline Menikah & 68 & $97 \%$ \\
\hline Belum Menikah & 2 & $3 \%$ \\
\hline \multicolumn{3}{|c|}{ D. Tanggapan terhadap shift lama } \\
\hline Nyaman & 31 & $44 \%$ \\
\hline Tidak Nyaman & 39 & $56 \%$ \\
\hline \multicolumn{3}{|c|}{ E. Tanggapan terhadap perubahan shift } \\
\hline Tidak setuju & 18 & $26 \%$ \\
\hline Ragu - ragu & 9 & $13 \%$ \\
\hline Setuju & 43 & $61 \%$ \\
\hline
\end{tabular}

\section{Uji Validitas}

Pengujian Validitas ini dilakukan dengan menghitung korelasi skor penilaian seluruh responden pada setiap faktor dengan skor total seluruh faktor. Penghitungan dilakukan dengan software SPSS. Data dinyatakan valid0 jika nilai Corrected Item Total Correlation nya lebih 
besar dari nilai kritis yang diperoleh dari tabel. Data-data yang ada adalah sebagai berikut

$$
\begin{array}{ll}
\mathrm{n} & =70 \\
\text { derajat kebebasan } & =\mathrm{n}-3=67 \\
\alpha & =5 \% \\
\mathrm{r} \text { tabel } & =0.232
\end{array}
$$

Jika nilai $r$ setiap atribut lebih besar dari $\mathrm{r}$ tabel, maka atribut tersebut dikatakan valid, berarti responden dalam menilai kriteria variabel tidak mengalami bias yang besar dalam memahami kuesioner, sehingga persepsi terhadap kuesioner tersebut tidaklah

\begin{tabular}{|c|c|c|c|c|}
\hline \multicolumn{5}{|c|}{ Item-total Statistics } \\
\hline & Scale & Scale & Corrected & \\
\hline & Mean & Variance & Item: & Alpha \\
\hline & & & & \\
\hline & Deleted & Deleted & Correlation & Deleted \\
\hline FAKTOR1 & 41.7571 & 18.8532 & .3138 & .7376 \\
\hline FAKTOR2 & 41.5429 & 19.1793 & .3968 & .7207 \\
\hline FAKTOR3 & 41.3000 & 19.5174 & .4649 & .7137 \\
\hline FAKTOR4 & 41.5143 & 18.8621 & .4174 & .7178 \\
\hline FAKTOR5 & 40.9571 & 19.6938 & .5242 & .7103 \\
\hline FAKTOR6 & 41.4286 & 19.0890 & .3653 & .7258 \\
\hline FAKTOR7 & 41.5571 & 19.0039 & .3547 & .7280 \\
\hline FAKTOR8 & 41.4286 & 19.2050 & .4918 & .7097 \\
\hline FAKTOR9 & 40.7000 & 21.2565 & .3731 & .7299 \\
\hline FAKTOR10 & 41.2286 & 19,4253 & .2801 & .7408 \\
\hline FAKTOR11 & 41.3000 & 19,4014 & .5049 & .7097 \\
\hline
\end{tabular}
berbeda. Berikut ini adalah hasil pengujian validitas tersebut :

RELIABILITY ANALYSIS - SCALE (ALPHA)

Dari hasil kuesioner karyawan yang berjumlah 70 orang pada unit maintenance terhadap tingkat stress kerja di dapatkan nilai terendah adalah 31 dan nilai tertinggi adalah 55, hal ini menyimpulkan bahwa terdapat tingkat stress yang tinggi terhadap shift kerja yang berlaku saat ini. Lebih lengkapnya dapat dilihat pada gambar berikut :

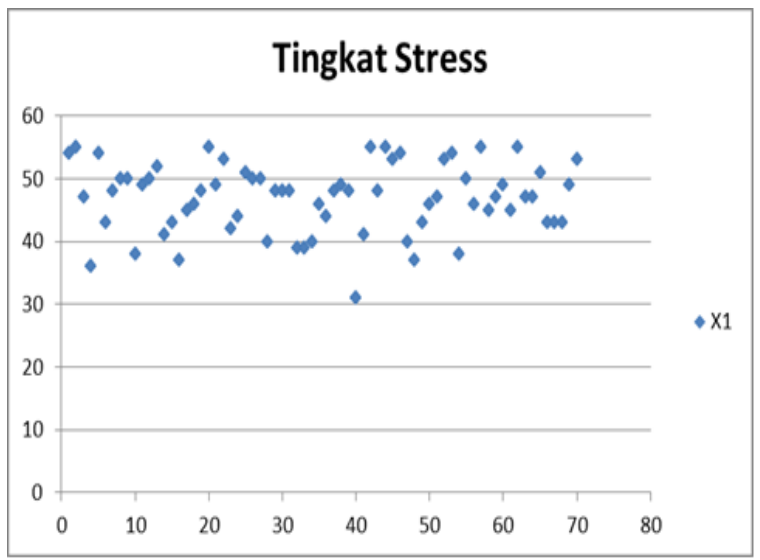

Gambar: Tingkat strees

\section{Tingkat Kelelahan}

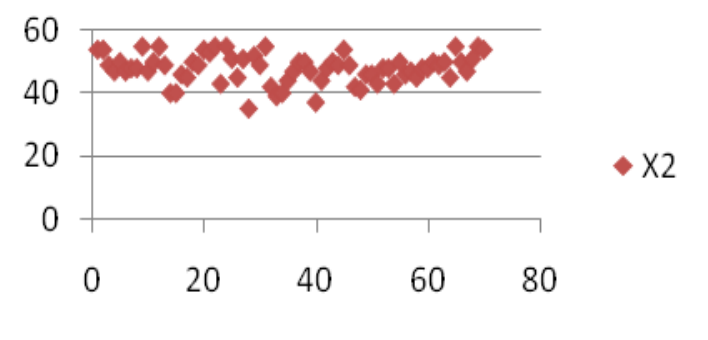

Gambar: Tingkat kelelahan

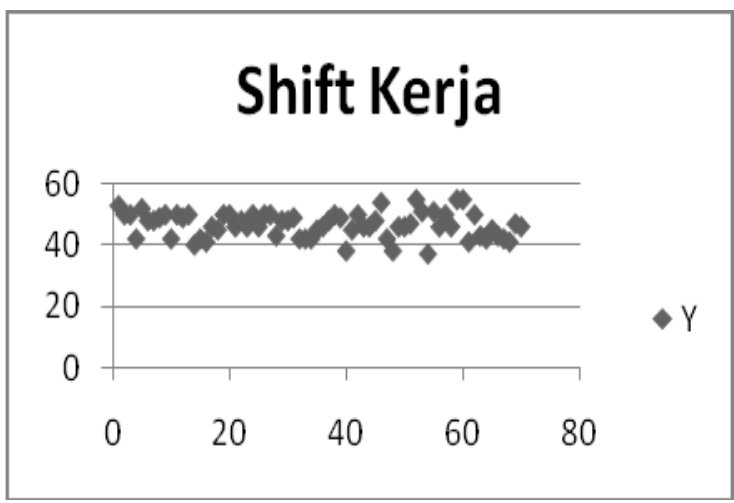

Gambar Shift Kerja

\section{E. Hasil Penelitian}

Hasil penelitian mengenai input bahan baku, maintenance dan sistem kerja terhadap kualitas air pada PT. Tirta Cisadane - Serpong, didapatkan skor tertinggi ada pada masalah sistem kerja yang kurang nyaman pada shift shift tertentu, sehingga memeiliki tingkat kepentingan yang tinggi untuk segera dilakukan improvement. Berikut diagram pareto untuk menampilkan nilai skor masalah tertinggi yang terjadi sebagai berikut:

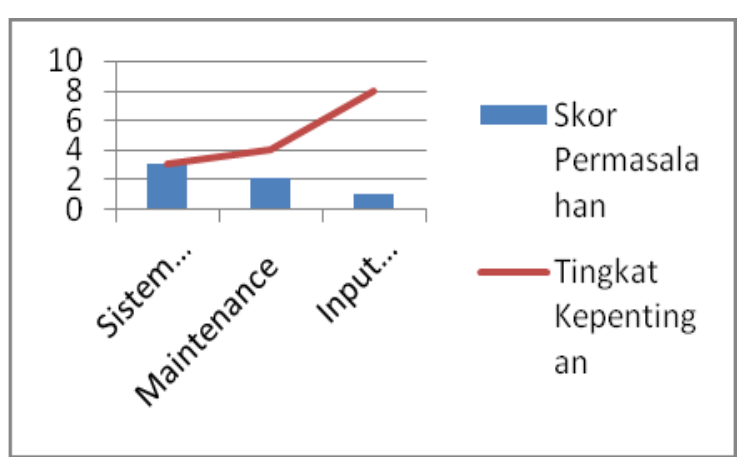

Gambar: Diagram Pareto 


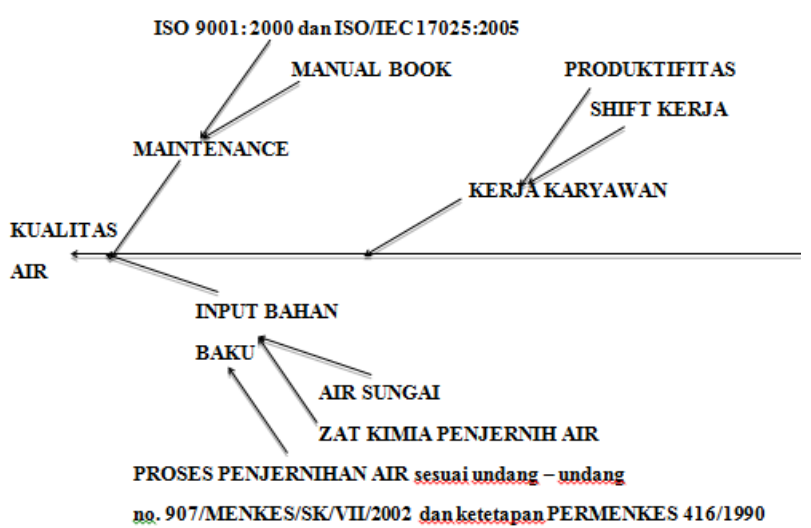

\section{F.Penerapan Shift Baru}

Dengan hasil yang diperoleh dari pengolahan data di atas, maka dibuatlah desain shift kerja yang baru. Pembuatan desain kerja baru berdasarkan pertanyaan pada kuesioner III untuk menguji faktor shift kerja terhadap tingkat stress dan kelelahan dalam bekerja dan mayoritas karyawan di bagian maintenance menginginkan adanya perubahan shift kerja.

Tabel Perbandingan Shift Kertja Lama dan Baru

\begin{tabular}{|c|c|c|c|}
\hline No. & Faktor & Shift Lama & Shift Baru \\
\hline 1. & Jenis Shift & Berotasi & Berotasi \\
\hline 2. & Panjang Shift & $8 \mathrm{Jam}$ & $8 \mathrm{Jam}$ \\
\hline 3. & $\begin{array}{l}\text { Waktu istirahat : } \\
\text { a. Tiap hari kerja }\end{array}$ & $\begin{array}{l}\text { Shift Pagi : } 12.00-13.00 \\
\text { Shift Sore : } 20.00-21.00 \\
\text { Shift Malam : 02.00-03.00 } \\
2 \text { Hari }\end{array}$ & $\begin{array}{l}\text { Shift Pagi : } 11.30-12.30 \\
\text { Shift Sore : } 19.30-20.30 \\
\text { Shift Malam : 03.00-04.00 } \\
2 \text { Hari }\end{array}$ \\
\hline 4. & Arah perputaran & Perputaran shift maju & Perputaran shift maju \\
\hline 5. & Perputaran shift & 2-2-2 beraturan & 2-2-2 beraturan \\
\hline 6. & Jam kerja & $\begin{array}{l}\text { Shift Pagi : 06.00-14.00 } \\
\text { Shift Sore : } 14.00-22.00 \\
\text { Shift Malam : 22.00-06.00 }\end{array}$ & $\begin{array}{l}\text { Shift Pagi : 07.00-15.00 } \\
\text { Shift Sore : } 15.00-23.00 \\
\text { Shift Malam : 23.00-07.00 }\end{array}$ \\
\hline 7. & $\begin{array}{l}\text { Jumlah jam kerja } \\
\text { tiap } 1 \text { bulan }\end{array}$ & $8 \times 24 \mathrm{jam} /$ bulan & $8 \times 24 \mathrm{jam} / \mathrm{bulan}$ \\
\hline 8. & $\begin{array}{l}\text { Jumlah shift tiap } \\
\text { satu orang dalam } \\
1 \text { bulan }\end{array}$ & $\begin{array}{l}\text { Shift Pagi : } 8 \text { Hari } \\
\text { Shift Sore : } 8 \text { Hari } \\
\text { Shift Malam : } 8 \text { Hari } \\
\text { Istirahat : } 7 \text { Hari }\end{array}$ & $\begin{array}{l}\text { Shift Pagi : } 8 \text { Hari } \\
\text { Shift Sore : } 8 \text { Hari } \\
\text { Shift Malam : } 8 \text { Hari } \\
\text { Istirahat : } 7 \text { Hari }\end{array}$ \\
\hline
\end{tabular}

\section{KESIMPULAN}

Berdasarkan analisis terhadap penerapan input bahan baku, maintenance dan sistem kerja karyawan di PT. Tirta Cisadane Serpong, dengan menggunakan sistem seven tools sehingga dapat diambil kesimpulan sebagai berikut:

1. Dalam menggunakan metode seven tools kita dapat mengetahui bagian mana yang perlu dilakukan improvement terlebih dahulu terutama menggunakan diagram fish bone.

2. Dalam hal input bahan baku sudah sesuai parameter kualitas air bersih yang di tetapkan dalam PERMENKES 416/1990 terdiri atas persyaratan fisik, persyaratan kimiawi, persyaratan mikrobiologis maka dilakukan WTP atau Water Treatment Proses dengan kata lain pengolahan air serta sesuai Keputusan Menteri Kesehatan no. 907/MENKES/SK/VII/2002 tentang syarat-syarat dan pengawasan kualitas air minum sehingga tidak diperlukan improvement yang berarti.

3. Tidak di temukannya kerusakan yang berarti pada mesin pengolahan air di PT. Tirta Cisadane-Serpong, karena pengoperasiannya sudah sesuai manual book itu sendiri sehingga preventive maintenance, breakdown maintenance dan corrective maintenance sudah terjadwal. 


\section{DAFTAR PUSTAKA}

Arikunto, S. (1998). Prosedur Penelitian Suatu Pendekatan Praktek. Rineka Cipta. Yogyakarta.

Grandjean (1986). Night Work and Shift Work in Fitting The Task to The Man: An Ergonomic Approach. Taylor \& Francis, London \& Philadelphia.

Heizer, Jay, and Render, Barry (2009). Operations Management : Sumber Daya Manusia dan Rancangan Kerja.

Lanfranchi, J., Henry Ohlsson, dan Ali Skalli (2001). Compensating Wage Differentials and Shift Work Preferences : Evidence from France. JEL, J28, J31, J33.

Nurmianto, E. dan A. Teguh Siswantoro (2000). Manajemen Shift Kerja pada Industri Jasa Perhotelan.Jurnal Teknologi Industri Universitas Atmajaya Jogjakarta, pp.55-66.

Peter Knauth, HP (1988). The Design of Shift Systems, International Journal of Industrial Ergonomics 3, pp.77-81.

Pheasant, Stephan (1996). Ergonomi, Work and Health, Max Millan Press.

Pribadi, Sri Rejeki Wahyu (1998). Perancangan Shift Kerja Sebagai Usaha Peningkatan Performansi Karyawan di Dept. Engineering Hotel IBIS Rajawali Surabaya.

Suma'mur, P.K. (1984). Ergonomi untuk Produktivitas Kerja. Yayasan Swabhawa Karya. Jakarta.

Weiten, Weyne (1992). Psychology, Themes and Variations, Second Edition, Brooks / Cole Publishing Company, Pacific Grove, California.

http://www.angkasaonline.com/09/12/cakra/cakra1 
